\title{
Dry single-stage method of sodium tripolyphosphate production - technological and economic assessment
}

\author{
Katarzyna Gorazda*, Zygmunt Kowalski, Regina Kijkowska, Danuta Pawłowska-Kozińska, \\ Zbigniew Wzorek, Marcin Banach, Anna K. Nowak \\ Cracow University of Technology, Institute of Inorganic Chemistry and Technology, Warszawska 24, 31-155 Kraków, Poland \\ "Corresponding author: e-mail: gorazda@chemia.pk.edu.pl
}

\begin{abstract}
The study presents a technology of sodium tripolyphosphate (STPP) production with the use of a dry, single-stage method. The reacting substrates (concentrated wet-process phosphoric acid - WPPA and solid $\mathrm{Na}_{2} \mathrm{CO}_{3}$ ) are mixed with a recycled final product (STPP) in a mixer, then a ,quasi-dry" mixture is calcined in a rotary kiln. Thanks to that, some stages of a classic method of STPP production are eliminated: one of the two-stage neutralization of the phosphoric acid with sodium carbonate at temperature $\sim 80^{\circ} \mathrm{C}$, filtration of the neutralised solution and its evaporation, as well as the stage of drying a solution of mono- and di-sodium orthophosphate in a spray dryer. According to the presented technical and economical analysis, the costs of STPP production using a single-stage dry method can be $10 \%$ lower compared to the classic method.
\end{abstract}

Keywords: sodium tripolyphosphate production, dry method, classic method, technical and economic analysis.

\section{INTRODUCTION}

Sodium tripolyphosphate (STPP) is used as a builder of washing powders and other cleaning agents. Many beneficial features of STPP are the reason for the common use of the compound: buffering properties, ability to sequestrate calcium and magnesium ions, ability to deflocculate and disperse dirt particles as well as to emulsify fat ${ }^{1-4}$.

Condensed sodium pyro- and polyphosphates are usually produced with the use of a multi-stage method that consists of neutralization and two-stage dehydration ${ }^{1,2,5}$. The first stage of sodium tripolyphosphate production is the neutralization of wet process phosphoric acid (WPPA) using soda, usually conducted in two stages in separate neutralisation reactors at the final mole ratio $\mathrm{Na} / \mathrm{P}=5 / 3 \approx 1.67$. The obtained solution consists of a mixture of mono- and disodium orthophosphates that is introduced to evaporation after filtration. The second stage is drying in spray dryers, where the compounds are being condensed. At the third stage the mixture of pyrophosphates from the second stage is calcined in a rotary kiln, which results in further condensation to sodium tripolyphosphate.

The single methods for STPP production are also reported in the literature. In that methods drying and calcination are one technological operation carried out in a rotary kiln, with a drying chamber, or in a fluidized bed $^{5-7}$.

This study presents the technology of sodium tripolyphosphate production using the single-stage dry method as well as its economical analysis ${ }^{8}$. The method allows to eliminate one of the two-stage neutralization of phosphoric acid with sodium carbonate as well as filtration and evaporation of that solution, and the energy consuming stage of drying in a spray dryer.

\section{INTRODUCTION OF DEVELOPED SINGLE-STAGE DRY METHOD}

Single-stage dry method (Fig. 1) consists in mixing of reacting substances - concentrated WPPA and powde-

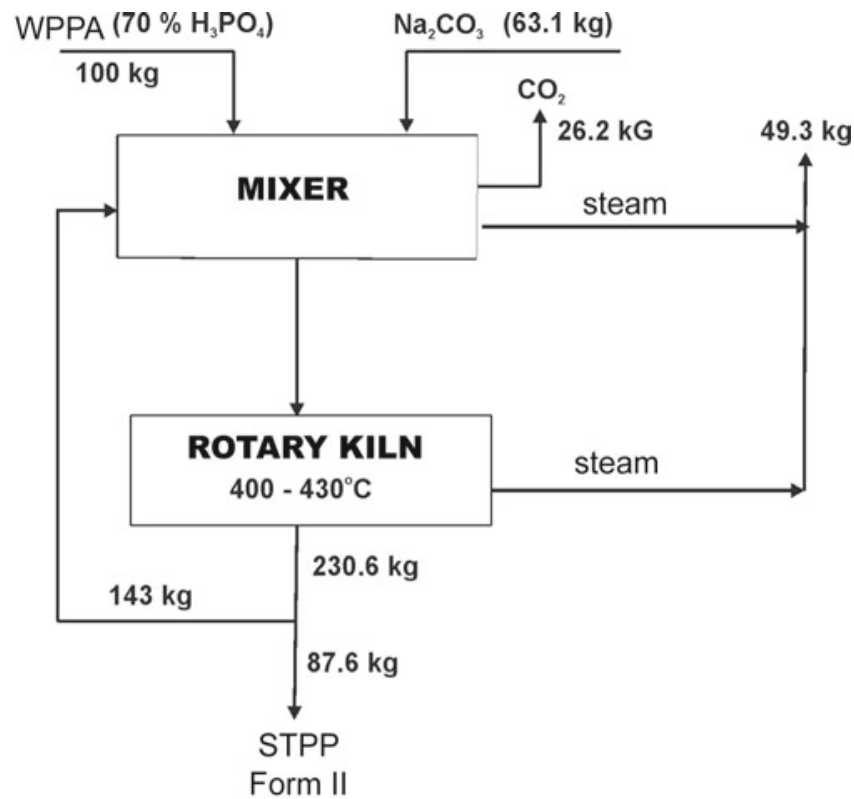

Figure 1. Flow sheet of the STPP production using single-stage dry method

red $\mathrm{Na}_{2} \mathrm{CO}_{3}$ (a dosage compliant with the mole ratio $\mathrm{Na} / \mathrm{P}=5 / 3$ required for obtaining $\left.\mathrm{Na}_{5} \mathrm{P}_{3} \mathrm{O}_{10}\right)$ - with a recycled product (STPP) in a mixer, and then feeding the obtained "quasi-dry" mixture into a rotary kiln. Due to an adequate choice of proportions of a solid and liquid phase, the obtained mixture has the consistency of moist, fine sand, which does not lump and can be carried with a screw or Redler conveyor.

The obtained mixture of salts is calcined as in a classic method. After calcining, either a low temperature form of STPP (Form II) was obtained when the calcining temperature did not exceed $450^{\circ} \mathrm{C}$, or a high temperature form of STPP (Form I) was obtained when the temperature of calcining exceeded $500^{\circ} \mathrm{C}$. The results are consistent with our previous research and the literature data ${ }^{2,8,9}$.

In the case of using the recycled STPP (Form II) in a mixture of orthophosphates that are produced in a reaction (WPPA $+\mathrm{Na}_{2} \mathrm{CO}_{3}+$ recycled STPP) before they are calcined, the phase composition of a product does not depend on the kind of phosphoric acid used 
and its concentration. The phase composition of the product of the reaction using only WPPA $+\mathrm{Na}_{2} \mathrm{CO}_{3}$ depends on both the kind and the concentration of phosphoric acid ${ }^{2,8}$.

If we use the recycled STPP in Form II in the mixture of orthophosphates we will also obtain (both in a rotary kiln $\left(430^{\circ} \mathrm{C}\right)$ and in a stationary chamber furnace $\left.\left(400^{\circ} \mathrm{C}\right)\right)$ Form II of STPP as a product. Recycling of STPP as Form II results in the inoculation of a new product. The new product is also an STPP-Form II independent of its calcining in a chamber furnace or in a rotary kiln, under the condition that the temperature of calcining does not exceed $500^{\circ} \mathrm{C}$ as was reported and in our previous research ${ }^{2,8}$.

The technological products obtained with the use of the dry single-stage method is sodium tripolyphosphate $\mathrm{Na}_{5} \mathrm{P}_{3} \mathrm{O}_{10}$ :

- powdered and heavy, with a low content of Form I,

- powdered with a high content of Form I

- granulated with variable density.

The characteristics of the products are shown in Table 1.

The method is similar, in a way, to a former method of a single-stage production of STPP in a rotary kiln in VEB Stickstoffwerk Piesteritz ${ }^{7}$ (Fig. 2). The classic process of sodium orthophosphates neutralization was used in this process. The obtained solution of sodium orthophosphates was injected directly into a kiln in parallel with a dosage of a recycled product. The ratio of

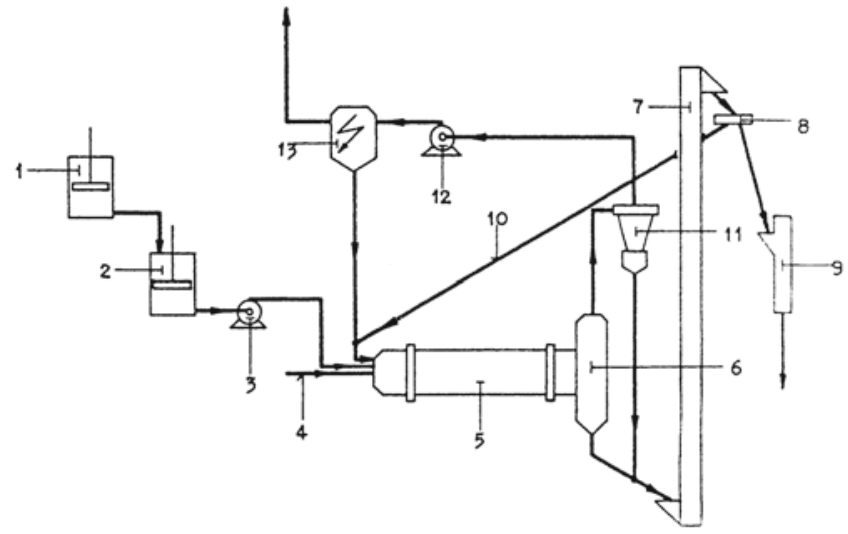

1, 2 - neutralization tanks, 3 - pump, 4 - natural gas input, 5 - rotary kiln, 6 - output chamber, 7 - elevator, 8 - rotary feed table, 9 - rod mill, 10- recycled product, 11 - cyclone, 12 - fan, 13 - electro-filter

Figure 2. Single-stage STPP production method used in VEB Stickstoffwerk Piesteritz ${ }^{7}$ the recycled product to the final product was 5:1. The difference between the currently described method and the quoted one is the use of concentrated WPPA that reduces the consumption of energy used for the evaporation of water from the system, as well as the use of a lower amount of the recycled STPP. This amount is indicated by a weight ratio STPP/WPPA $=1.43^{2,8}$.

A flow diagram of the dry single-stage method of STPP production is presented in Figure 3. A suitable amount of sodium carbonate, a final product (recycled into the process with conveyors and belt weighed) and $75 \%$ phosphoric acid (pumped with a pump through a dosing tank) are dosed into the neutralization mixer-reactor /1/ equipped with a heating jacket and a stirrer. A quasi-dry mixture from the reactor is dosed by a screw conveyor /2/ directly into a rotary kiln $/ 3 /$, heated by natural gas from a burner. After calcining the product is disintegrated in a hammer mill /4/ and transported into storage tanks. A part of the product is recycled into the reactor $/ 1 /$ using a screw conveyor $/ 5 /$. Exhaust gases from the rotary kiln are dedusted in a bag filter /6/ and pumped by a fan /8/ into a chimney /9/. Dust after dedusting is recycled with a screw conveyor $/ 7 /$ into the mixer-reactor $/ 1 /$.

Technological parameters of particular stages are as follows:

a) mixing - mixing of soda ash with WPPA containing $\sim 70 \% \mathrm{H}_{3} \mathrm{PO}_{4}$ and next with the recycled product and

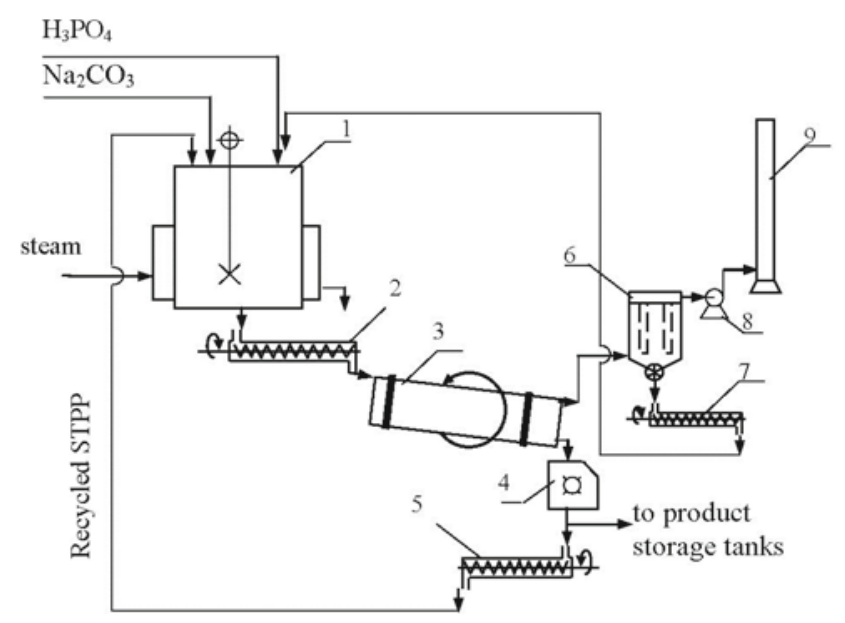

1 - neutralization mixer-reactor, 2, 5, 7 - screw conveyor, 3 rotary kiln, 4 - hammer mill, 6 - bag filter, 8 - fan, 9 - chimney

Figure 3. Single-stage, dry method of STPP production

Table 1. Characteristic of the STPP products obtained with the use of the dry single-stage method

\begin{tabular}{|c|c|c|c|}
\hline & Product 1 & Product 2 & Product 3 \\
\hline Characteristic & $\begin{array}{c}\text { powdered and heavy, with a low content } \\
\text { of Form I }\end{array}$ & $\begin{array}{c}\text { powder with a high content of } \\
\text { Form I } \\
\text { hydrated }\end{array}$ & variable density, granulated \\
\hline $\mathrm{Na}_{5} \mathrm{P}_{3} \mathrm{O}_{10}[\% \mathrm{w} / \mathrm{w}]$ & $\min .91$ & $\min .93$ & $\min .93$ \\
\hline $\mathrm{P}_{2} \mathrm{O}_{5}[\% \mathrm{w} / \mathrm{w}]$ & $\min .56$ & $\min .56$ & $\min .56$ \\
\hline $\mathrm{Fe}[\% \mathrm{w} / \mathrm{w}]$ & $\max -0.0080$ & $\max -0.0060$ & $\max -0.0060$ \\
\hline $\begin{array}{l}\text { Parts insoluble in } \mathrm{H}_{2} \mathrm{O} \\
{[\% \mathrm{w} / \mathrm{w}]}\end{array}$ & $\max .0 .20$ & $\max .0 .10$ & $\max .0 .15$ \\
\hline Form I [\%w/w] & $\max .4$ & $35-55$ & $\max .4$ \\
\hline Residues on a sieve [\%] & $\begin{array}{l}1 \mathrm{~mm}-\max .5-25 \\
0.15 \mathrm{~mm}-\max .1 .0\end{array}$ & $\begin{array}{l}1 \mathrm{~mm}-\max .5-25 \\
0.15 \mathrm{~mm}-\max .1 .0\end{array}$ & $\begin{array}{l}1.00 \mathrm{~mm}-\max 10 \\
0.85 \mathrm{~mm}-\max 30 \\
0.60 \mathrm{~mm}-35-65 \\
0.25 \mathrm{~mm}-\min -93\end{array}$ \\
\hline Bulk density $\left[\mathrm{kg} / \mathrm{m}^{3}\right]$ & $700-950$ & $800-1000$ & $1010-1070$ \\
\hline $\mathrm{pH}$ of $1 \%$ solution & $9-10$ & $9-10$ & $9-10$ \\
\hline
\end{tabular}


Table 2. Consumption figures of heat in STPP production $[G J / t]$

\begin{tabular}{|c|c|c|c|c|}
\hline \multicolumn{5}{|c|}{ Heat used for preheating a calcining charge at over $500^{\circ} \mathrm{C}$} \\
\hline & $\mathrm{M}$ & 1000 & $\mathrm{~kg}$ & \\
\hline & $\Delta \mathrm{t}$ & 500 & ${ }^{\circ} \mathrm{C}$ & \\
\hline & $\mathrm{C}_{\mathrm{w}}$ & 1.052 & $\mathrm{~kJ} / \mathrm{kg}$ deg & \\
\hline$Q$ & $\mathrm{M}^{*} \Delta \mathrm{t}^{*} \mathrm{C}_{\mathrm{w}}$ & 0.53 & $\mathrm{GJ} / \mathrm{t}$ & \\
\hline \multicolumn{5}{|c|}{ Heat used for evaporation of water and preheating a charge } \\
\hline Method & Spray dryer & Calciner & preheating a charge & Total \\
\hline Classic & 4.65 & 0.375 & 0.53 & 5.55 \\
\hline Dry single-stage & 0.00 & 1.74 & 0.53 & 2.27 \\
\hline
\end{tabular}

dust from the dedusting process. The temperature of the process is $\sim 20^{\circ} \mathrm{C}$; weight ratio of WPPA/soda $=1 / 0.63$; weight ratio of a recycled product to WPPA $=1.43 / 1$.

b/ calcining - kiln charge dosage $\sim 36 \mathrm{~kg} / \mathrm{m}^{2} / \mathrm{h}$, calcining time $\sim 45 \mathrm{~min}$, temperature $400-550^{\circ} \mathrm{C}$

In a currently used kiln with a surface of $138 \mathrm{~m}^{2}$ the rotary kiln working load is in the range of $36 \mathrm{~kg} / \mathrm{m}^{2} / \mathrm{h}$, and the time of calcining is about $45 \mathrm{~min}$ at the level of STPP capacity of $7.5 \mathrm{t} / \mathrm{h}$.

\section{RESULTS AND DISCUSSION}

The main advantage of the dry method is an opportunity to save considerable amounts of energy in comparison to the classic method. Estimated heat consumption in both methods is presented in Table 2. Amounts of water estimated for evaporation [kg/t STPP] were calculated as follows: Dry method - calcining - 463; classical method - dryer 930, rotary kiln - $100^{8}$. Assumed consumption figures of heat used for evaporation are according to Pikoń at a level of [MJ/kg of evaporated water]: 5.00 for a spray dryer and 3.75 for a rotary kiln ${ }^{\mathbf{1 0}}$.

Basing on the data from Table 2 the total savings of heat consumption can be estimated at $3.29 \mathrm{GJ} / \mathrm{t}$ STPP produced with the use of the dry single-stage method, in comparison to STPP produced with the use of the classic method.

The conducted studies showed electricity consumption of additional devices implementation in comparison to the dry method, and on this basis the consumption of
Table 3. Characteristics, cost evaluation of apparatus, devices and investment consumption

\begin{tabular}{|c|c|c|c|}
\hline $\begin{array}{c}\text { Diagram } \\
\text { item }\end{array}$ & Device & Quantity & $\begin{array}{c}\text { Estimated } \\
\text { cost [PLN] }\end{array}$ \\
\hline 1 & $\begin{array}{c}\text { Single-shafted mixer } \\
\begin{array}{c}\mathrm{V}=5 \mathrm{~m}^{3}, \text { vaned, with } \\
\text { a variable setting of } \\
\text { vanes }\end{array}\end{array}$ & 1 & 100.000 \\
\hline \multicolumn{2}{|c|}{ Total (purchase or execution costs) } & 100.000 \\
\hline \multicolumn{2}{|c|}{ Electric, measuring and control works } & 50.000 \\
\hline \multicolumn{2}{|c|}{ Assembling } & 230.000 \\
\hline \multicolumn{2}{|c|}{ Total costs } \\
\hline
\end{tabular}

electrical power was calculated ${ }^{8}$. Anticipated additional consumption of electric energy for usage by engines will be about $7.5 \mathrm{kWh}$ per ton of a product. Because the new dry process does not require spray drying (spray dryer power installed is $400 \mathrm{~kW}$ ) we can assume that the reduction in electricity consumption figure will be about $30.4 \mathrm{kWh} / \mathrm{t} \mathrm{STPP}$ in comparison to the classic process.

Studying the possibility of implementation of a dry single-stage method we assumed a substitution of a drying system with a mixing stage. Other devices remain without any change. The specification and a list of particular devices and machines together with their estimated investment costs is presented in Table 3. This implementation does not require any additional employment. The investment costs are relatively low.

There is no liquid or solid waste in the process. Elimination of the spray drying stage will totally eliminate the emission of alkaline dust.

Table 4. STPP production costs comparison - classic and dry single-stage method [\%]

\begin{tabular}{|c|c|c|c|}
\hline \multirow{2}{*}{ Item } & \multirow{2}{*}{ Calculations } & \multicolumn{2}{|c|}{ Participation in production costs [\%] } \\
\hline & & classic & dry single-stage \\
\hline 1 & Direct materials & 72.0 & 72.00 \\
\hline 2 & Purchasing cost & 7.20 & 7.20 \\
\hline 3 & Technological fuel & 10.00 & 3.08 \\
\hline 4 & Total cost of materials [no 1-3] & 89.20 & 82.28 \\
\hline 5 & Technological energy & & \\
\hline & Electricity [kWh] & 1.80 & 0.49 \\
\hline & Water $\left[\mathrm{m}^{3}\right]$ & 0.01 & 0.01 \\
\hline & Compressed air $\left[\mathrm{m}^{3}\right]$ & 0.10 & 0.10 \\
\hline 6 & Direct salaries & 1.30 & 1.30 \\
\hline 7 & Total direct costs [no 4-6] & 92.41 & 84.18 \\
\hline 8 & Indirect salaries & 0.59 & 0.59 \\
\hline 9 & Amortization & 3.00 & 1.00 \\
\hline 10 & Repairs and maintenance & 1.50 & 0.75 \\
\hline 11 & Occupational Health and Safety costs & 0.50 & 0.50 \\
\hline 12 & Environmental fees & 0.50 & 0.30 \\
\hline 13 & Non-technologic energy [kWh] & 0.10 & 0.10 \\
\hline 14 & Other costs & 0.20 & 0.20 \\
\hline 15 & Costs of chemical analysis & 0.20 & 0.20 \\
\hline 16 & Other indirect costs & 1.00 & 1.00 \\
\hline 17 & Total indirect costs [no 8-16] & 7.59 & 4.64 \\
\hline 18 & Department costs & 1.00 & 1.00 \\
\hline 19 & Gross production costs [no $7+17$ ] & 100.00 & 89.82 \\
\hline 20 & Admissed by-products & 0.00 & 0.00 \\
\hline 21 & Net production costs [no $19+20$ ] & 100.00 & 89.82 \\
\hline
\end{tabular}


The consumption of natural gas compared to the classic method will be lower at about $141 \mathrm{~m}^{3} / \mathrm{t}$ of a product due to the elimination of a spray drying stage.

Table 4 presents a comparison of STPP production costs with the use of the classic and dry single-stage method. The calculation made was based on the above mentioned figures of raw materials and energy consumption. The following assumptions were taken into account:

- raw materials costs are the same for both methods,

- amortization in the dry method is $50 \%$ lower than in the classic method,

- repair costs equal $50 \%$ of amortization costs,

- other costs are at the same level.

\section{CONCLUSIONS}

The presented analysis shows that the costs of STPP production with the use of developed dry single-stage method are more than $10 \%$ lower than the costs of the classic method. It is a considerable reduction in production costs. The implementation of the dry single-stage method does not require any additional employment. The investment costs are also relatively low. The dry single-stage method has lower consumption figures in comparison to the classic method. The total saving of heat consumption can be estimated at $3.29 \mathrm{GJ} / \mathrm{t}$ STPP and the consumption of electricity is estimated to be 30.4 $\mathrm{kWh} / \mathrm{t} \mathrm{STPP}$ lower than in the former process. Due to the elimination of a spray drying stage the consumption of natural gas will be lower at about $141 \mathrm{~m}^{3} / \mathrm{t}$ of a product.

\section{LITERATURE CITED}

1. Wzorek, Z. (2002). Operational properties of sodium tripoliphosphate. Technical Transactions, Chemistry 3, 67-73 (in Polish).

2. Kijkowska, R., Kowalski, Z., Pawłowska-Kozińska, D., Wzorek, Z. \& Gorazda, K. (2008). Tripolyphosphate made from Wet-process Phosphoric Acid with the use of a rotary kiln. Ind. Eng. Chem. Res. 47, 6821-6827. DOI: 10.1021/ie800412q.

3. Broze, G. (1999). Handbook of Detergents, Part A: Properties, CRC Press.

4. CEEP. (2007). Function of phosphates in detergents. Retrieved July 14, 2008, from http://www.ceep-phosphates.org

5. Kowalski, Z., Kijkowska, R., Pawłowska-Kozińska, D. \& Wzorek, Z. (2002). Sodium tripolyphosphate and others condensed sodium phosphates production methods. Pol. J. Chem. Tech. 4(3), 27-33.

6. King, C.S. (1947). US Patent No. 2419147. Washington, D.C.: U.S. Patent and Trademark Office.

7. Zobel, D., Kuchler, K., Oppermann, H. \& Soyka, H. (1977). Patent no. DE2121885. German Patent and Trademark Office.

8. Kowalski, Z., Kijkowska R., Pawłowska-Kozińska, D., Wzorek, Z., Gorazda, K. \& Banach, M. (2008). Report from realization of research project for State Committee for Scientific Research, The new technological solutions of sodium tripoliphosphate and sodium pyrophosphate production processes. Unpublished, Kraków, Poland (in Polish).

9. Van Wazer, J.R. (1958). Phosphorus and Its Compounds. New York, USA: Interscience Publishers.

10. Pikoń, K. (1970). Aparatura Chemiczna. Warszawa, WNT. 